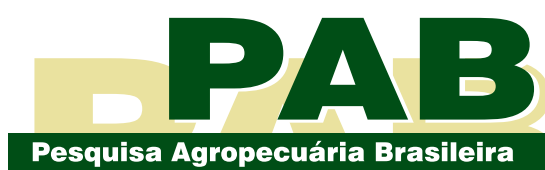

ISSN 1678-3921

Journal homepage: www.embrapa.br/pab

For manuscript submission and journal contents, access: www.scielo.br/pab

\title{
Yield stability of common bean genotypes in the state of Santa Catarina, Brazil
}

\begin{abstract}
The objective of this work was to evaluate the grain yield and stability of common bean genotypes, as well as the representativeness and discrimination ability of locations in multi-environment trials (METs), using the GGE biplot analysis. The grain yield of 27 genotypes was evaluated in 16 trials carried out in nine locations, in the state of Santa Catarina, Brazil, during the first and second crop seasons of 2014/2015 and 2015/2016. A randomized complete block design with three replicates was used. As the trials were neither conducted in all locations, nor in all growing seasons of both years, a highly unbalanced dataset was used. Genotype 5 (CHC 01-175-1) was the most productive and stable, common bean genotype and can be considered the closest one to the ideal for the target region. Furthermore, this genotype performs well in both crop seasons, outperforming all the evaluated checks; therefore, it has the potential to be released as a new cultivar. Chapecó can be considered the ideal location for the selection of common bean genotypes, in the state of Santa Catarina, since it shows high representativeness and discrimination ability in the rainy and dry crop seasons.
\end{abstract}

Index terms: Phaseolus vulgaris, genotype $\times$ environment interaction, GGE biplot, multivariate analysis, representativeness and discrimination ability.

\section{Estabilidade produtiva de genótipos de feijão no estado de Santa Catarina}

Resumo - O objetivo deste trabalho foi avaliar o rendimento de grãos e a estabilidade de genótipos de feijão, além da representatividade e da discriminância de locais em ensaios multiambientes, por meio de análises GGE biplot. O rendimento de grãos de 27 genótipos foi avaliado em 16 ensaios, realizados em nove locais do estado de Santa Catarina, Brasil, na primeira e na segunda safras de 2014/2015 e 2015/2016. Utilizou-se um delineamento experimental de blocos ao acaso, com três repetições. Como os testes não foram realizados em todos os locais nem em todas as estações de cultivo de ambos os anos, um conjunto de dados altamente desbalanceado foi usado. O genótipo 5 (CHC 01-175-1) foi o mais produtivo e estável, e pode ser considerado o mais próximo ao ideal para a região-alvo. Além disso, esse genótipo apresentou desempenho satisfatório tanto para a primeira quanto para a segunda safras, tendo superado o desempenho de todas as testemunhas utilizadas nos ensaios; portanto, esse genótipo tem potencial para ser lançado como uma nova cultivar. Chapecó pode ser considerado o local ideal de seleção de genótipos de feijão, no estado de Santa Catarina, pois apresenta elevada discriminância e representavidade, tanto para primeira quanto para a segunda safra.

Termos para indexação: Phaseolus vulgaris, análise multivariada, interação genótipo $\times$ ambiente, GGE biplot, representatividade e discriminância. 


\section{Introduction}

Common bean (Phaseolus vulgaris L.) is a leguminous species that constitutes an excellent source of proteins, carbohydrates, and minerals. As a staple and low-cost protein source, it is of great importance for developing countries, such as Brazil. In the 2019/2020 crop year, Brazilian production was about 3.2 million tonnes, and the Santa Catarina state was responsible for about 100 thousand tonnes (Conab, 2021). In this sense, Brazil is the third largest producer worldwide (FAO, 2019). Common bean is one of the most important components of the Brazilian diet, with a per capita consumption of $15 \mathrm{~kg}$ per year, according to Ferreira et al. (2018).

One of the main objectives of plant breeding is to direct the selection of cultivars in their most suitable cultivation environments and, to do this, performance evaluations of genotypes in different environments are carried out (Woyann et al., 2019). Environment (including sowing time, year, and cultural practices) can be defined as the result of the biophysical components that influence the development and growth of plants (Zimmermann et al., 2017). In this sense, the genotype $\times$ environment interaction $(\mathrm{GxE})$ can have a high impact on several crop traits, especially on grain yield. GxE can be defined as differentiated genotypic expressions in different environments, which reduce the association between phenotype and genotype and affect the genetic progress in breeding programs (Van Eeuwijk et al., 2016).

Data from multi-environment trials (MET) are necessary to assess the presence of GxE and to verify the adaptability and stability of a genotype and its grain yield potential (Yan, 2014). Adaptability can be defined as the ability of a genotype to respond predictably to environmental stimuli. Stability indicates the predictability of the performance of a genotype in different environments (Matei et al., 2017). Over the years, several methods to evaluate adaptability and stability have been described in the literature, differing according to the statistical methods used, such as the analysis of variance, parametric and nonparametric regressions, mixed-models, and multivariate analysis (Bornhofen et al., 2017). Multivariate statistics facilitate the understanding of complex GxE (Carvalho et al., 2016). Within the multivariate analysis, the genotypic main effect plus genotype-by-environment interaction (GGE) methodology uses GGE biplots to summarize data into few principal components (PC) (Yan, 2015). This methodology groups the principal effect of the genotype and the genotype $\times$ environment interaction $(\mathrm{G}+\mathrm{GE})$ in an additive manner (Yan, 2014).

Specific GGE biplots can be used to assess mean and stability and to identify the "ideal" genotype, that is, a hypothetical genotype that has a maximum yield and high stability (Yan, 2015). Additionally, environmental characteristics can be identified, such as representativeness and discrimination ability of test environments. Furthermore, the association between genotypes and environments can be verified. All these analyses make it easier the identification of the environment where the selection should be made, the recommendation of cultivars, and the selection of lineages for release (Qin et al., 2015). The main contribution of this study is to provide the first identification of the ideal location in Santa Catarina state, to conduct a common bean breeding program and to select a new common bean genotype for the state.

The objective of this work was to evaluate the grain yield and stability of common bean genotypes, as well as the representativeness and discrimination ability of locations in multi-environment trials conducted in the state of Santa Catarina, Brazil, using the GGE biplot analysis.

\section{Materials and Methods}

A total of 16 trials were carried out in 11 cultivation environments distributed in nine locations, in the state of Santa Catarina, Brazil, during both the rainy and dry growing seasons of 2014/2015 and 2015/2016 crop seasons (Table 1). For simplicity, the location and growing seasons were grouped. This way, the location Chapecó constitutes the environments L41 and L42 for the rainy and dry growing seasons, respectively. Thus, the dataset can be described as highly unbalanced, which is common in METs.

The treatments consisted of 27 bean genotypes from four breeding programs: Epagri (Empresa de Pesquisa e Extensão Rural de Santa Catarina), Iapar (Instituto de Desenvolvimento Rural do Paraná), Embrapa (Empresa Brasileira de Pesquisa Agropecuária), and IAC (Instituto Agronômico) (Table 2). In addition, four commercial cultivars were used as checks. Among the genotypes from the breeding programs, 
14 had pinto-type grains, and seven had black-type grains; in addition, two genotypes showed mulatinho and mourinho special-type grains (Table 2). Specialtype grains have teguments with white, red, cream, yellow, or other coloration, with either the absence or presence of mottled, striped, or stippled patterns (Ribeiro et al., 2014). Furthermore, two checks showed pinto-type grains, and the other two had black-type grains. Genotypes with different types of grains were evaluated together, since new genotypes are released based on their performance, and no specific grain type is preferred.

The trials were carried out in a randomized complete block design, with four replicates. The plots consisted of four $5 \mathrm{~m}$ long rows, spaced at $0.45 \mathrm{~m}$, with 240,000 plants ha ${ }^{-1}$ density of. Sowing in the rainy and dry growing seasons, for both years, was carried out in the first half of November and February, respectively. Sowing was carried out in succession to black oat (Avena strigosa Schreb.) in all locations. The fertilization consisted of $6 \mathrm{~kg} \mathrm{ha}^{-1} \mathrm{~N}, 60 \mathrm{~kg} \mathrm{ha}^{-1} \mathrm{P}_{2} \mathrm{O}_{5}$, and $45 \mathrm{~kg} \mathrm{ha}^{-1} \mathrm{~K}_{2} \mathrm{O}$ (using $300 \mathrm{~kg} \mathrm{ha}^{-1}$ of the $\mathrm{N}^{-} \mathrm{P}_{2} \mathrm{O}_{5^{-}}$ $\mathrm{K}_{2} \mathrm{O}$ 02-20-15 formula). In addition, urea fertilizer at a dose of $100 \mathrm{~kg} \mathrm{ha}^{-1}\left(46 \mathrm{~kg} \mathrm{ha}^{-1} \mathrm{~N}\right)$ was applied 20 days after emergence, in the phenological stage $V_{3}-V_{4}$. All cultural treatments were carried out according to the technical recommendations for common beans (Comissão Técnica Sul-Brasileira de Feijão, 2012). To reduce the experimental errors, only the two center rows were harvested, in a useful area of $4.5 \mathrm{~m}^{2}$. Harvest was performed with a harvesting machine.
Grain yield (GY) was obtained ( $\left.\mathrm{kg} \mathrm{ha}^{-1}\right)$ and adjusted to $13 \%$ humidity.

The analysis of GGL (genotype main effect + genotype $\times$ location interaction) + GGE (genotype main effects plus genotype-by-environment interaction) allowed of the evaluation of multiyear trials in a single biplot. Data were analyzed using the GGEbiplot software (Yan, 2001). The analysis of mean and stability was performed for the rainy and the dry growing seasons together, and then they were separated, to verify if the genotypes were specifically adapted to a growing season. For the mean and stability biplot, the following parameters were used: nontransformation (Transform $=0$ ), standard deviation (SD), standard data (scaling $=1$ ), and environmentcentered (centering $=2$ ). The biplot was based on the genotype-focused singular value partitioning $(\mathrm{SVP}=1)$ and was therefore appropriate for visualizing the similarities among genotypes. The single-arrowed line shows on the axis of the average environment coordination (AEC) abscissa points in the direction of higher mean performance of the genotypes. The double-arrowed line approximates the contributions of the genotypes to GE, which is a measure of their stability. A genotype located close to the AEC abscissa and with a near-zero projection onto the AEC ordinate is considered highly stable. For the ideal genotype analysis, the concentric circle indicates how close a genotype is to a hypothetical genotype that has a maximum yield and good stability.

Table 1. Characterization of locations and growing seasons (rainy and dry) combined as environments for trial evaluations of common bean genotypes, in the state of Santa Catarina, Brazil, in the 2014/2015 and 2015/2016 crop seasons.

\begin{tabular}{|c|c|c|c|c|c|c|c|c|c|}
\hline \multirow[t]{2}{*}{ Location } & \multirow{2}{*}{$\begin{array}{l}\text { Altitude } \\
(\mathrm{m})^{(1)}\end{array}$} & \multirow{2}{*}{$\begin{array}{l}\text { Annual tempera- } \\
\text { ture }^{(1)}\left({ }^{\circ} \mathrm{C}\right)\end{array}$} & \multirow{2}{*}{$\begin{array}{l}\text { Annual precipita- } \\
\operatorname{tion}^{(1)}(\mathrm{mm})\end{array}$} & \multirow[t]{2}{*}{ Soil type ${ }^{(2)}$} & \multicolumn{2}{|c|}{2014} & \multicolumn{2}{|c|}{2015} & \multirow[t]{2}{*}{ Environment $^{(3)}$} \\
\hline & & & & & Rainy & Dry & Rainy & Dry & \\
\hline Águas de Chapecó & 330 & 19.4 & 2,071 & Litólico eutrófico & - & $\mathrm{X}$ & - & - & L12 \\
\hline Campos Novos & 852 & 16.4 & 1,704 & Latossolo Bruno/roxo & $\mathrm{X}$ & - & - & - & $\mathrm{L} 21$ \\
\hline Canoinhas & 831 & 17.2 & 1,607 & $\begin{array}{l}\text { Latossolo Bruno/ } \\
\text { Vermelho-Escuro }\end{array}$ & $\mathrm{X}$ & - & $\mathrm{X}$ & $\mathrm{X}$ & L31 and L32 \\
\hline Chapecó & 582 & 18.1 & 2,069 & Terra Roxa estr. & $\mathrm{X}$ & - & $X$ & $X$ & L41 and L42 \\
\hline Ituporanga & 555 & 17.7 & 1,807 & Cambissolo álico & - & $\mathrm{X}$ & - & $\mathrm{X}$ & L52 \\
\hline Lages & 987 & 15.2 & 1,685 & Terra bruna estr. & $\mathrm{X}$ & - & - & - & L61 \\
\hline Ponte Serrada & 1,021 & 16.1 & 1,849 & Cambissolo Álico & $\mathrm{X}$ & - & $\mathrm{X}$ & - & L71 \\
\hline Urussanga & 238 & 18.6 & 1,480 & Podzólico ver/ama & - & $\mathrm{X}$ & - & $\mathrm{X}$ & L82 \\
\hline Xanxerê & 747 & 17.5 & 2,211 & Terra roxa estr. & - & $\mathrm{X}$ & - & - & L92 \\
\hline
\end{tabular}

${ }^{(1)}$ Alvares et al. (2013). (2)Potter et al. (2004). ${ }^{(3)}$ Environment consists of the combination of location and growing season, irrespectively if the trial was carried out in one or two years. For instance, location Chapecó constitutes environments L41 and L42 for the rainy growing season and the second growing season, respectively. 
The analysis of associations between genotypes and environments allowed of the identification of genotypes with better grain yield in each environment. The angle between the vectors represents the genetic correlation (Yan, 2014). A positive association between genotypes and the environments occurs when angles are smaller than $90^{\circ}$. Angles larger than $90^{\circ}$ represent a negative association (Yan, 2014). For this analysis, SVP $=2$ was used, that is, the analysis focused on the environment.

For the analysis of representativeness and discrimination ability, the smaller angle between the environment and the average environment indicates a higher representativeness. Likewise, when there is a smaller angle between the environments, the genetic correlation will be greater. When the data scaling method is based on the standard deviation (SD) +

Table 2. Genotypes and checks of common bean (Phaseolus vulgaris) evaluated in the state of Santa Catarina, Brazil, for the rainy and dry growing seasons, in the 2014/2015 and 2015/2016 crop seasons.

\begin{tabular}{lccc}
\hline $\begin{array}{l}\text { Identification } \\
\text { on biplot }\end{array}$ & Genotype & Breeding company & Grain type \\
\hline 1 & C10-2-4/41 & IAC & Pinto bean \\
2 & CHC 00-101-10 & Epagri & Pinto bean \\
3 & CHC 00-101-76 & Epagri & Pinto bean \\
4 & CHC 00-92-34 & Epagri & Pinto bean \\
5 & CHC 01-175-1 & Epagri & Pinto bean \\
6 & CHC 01-175-2 & Epagri & Pinto bean \\
7 & CHP 01-182-12 & Epagri & Black bean \\
8 & CHP 01-182-48 & Epagri & Black bean \\
9 & CHP 04-239-01 & Epagri & Black bean \\
10 & CHP 04-239-52 & Epagri & Black bean \\
11 & CHP 04-239-61 & Epagri & Black bean \\
12 & CHC 97-29-07 & Epagri & Pinto bean \\
13 & CHC 98-42 & Epagri & Pinto bean \\
14 & CHP 99-65-24 & Epagri & Black bean \\
15 & CNFC 11948 & Embrapa Arroz e Feijão & Pinto bean \\
16 & CNFC 11954 & Embrapa Arroz e Feijão & Pinto bean \\
17 & FAP-F3-2 & IAC & Pinto bean \\
18 & LP 11-363 & Iapar & Pinto bean \\
19 & LP 12-601 & Iapar & Pinto bean \\
20 & TB 03-26 & Embrapa Clima Temperado & Mulatinho \\
21 & TB 03-27 & Embrapa Clima Temperado & Mourinho \\
22 & LEC 03-14 & Iapar & Pinto bean \\
23 & LEP 04-14 & Iapar & Black bean \\
24 & BRS Campeiro & Embrapa & Black bean \\
25 & IPR Uirapuru & Iapar & Black bean \\
26 & Pérola & Embrapa & Pinto bean \\
27 & SCS 202 Guará & Epagri & Pinto bean \\
\hline & & &
\end{tabular}

adjusted heritability $(\mathrm{H})$ (scaling 2), the vector length corresponds to the square root of $\mathrm{H}$ (Yan, 2014). Scaling 2 is the most adequate for evaluating environments for both representativeness and discrimination ability.

In the analyses of ideal genotypes and the association between environments and genotypes, scaling 1 was used, when all environments had the same weight and a similar vector. For the representativeness and discrimination ability of the environments, scaling 2 was used because the length of the vector is essential for the result (Yan, 2014). In the analyses of ideal genotypes, the SVP used was $\mathrm{SVP}=1$ because the focus was on genotypes. For the analyses of environments, $\mathrm{SVP}=2$ was used to identify the association between locations and their discrimination ability.

\section{Results and discussion}

The analysis of variance for grain yield indicated a triple interaction between genotypes $(\mathrm{G})$, years $(\mathrm{Y})$, and environments (E) (Table 3). It showed the presence of $\mathrm{GxE}$ and differential performance of genotypes over the years of evaluation and environments. The principal effects of environment and year represented the largest part of the grain yield variance, corroborating other studies on common bean (Santos et al., 2019; Zanella et al., 2019). The junction of the location and the seasons (rainy, or dry) likely contributed also, but this is not a relevant factor, since the possible new common

Table 3. Summary of the analysis of variance, for grain yield of 27 common bean (Phaseolus vulgaris) genotypes evaluated in 11 environments (location $\times$ growing season), in the 2014/2015 and 2015/2016 crop seasons, in the state of Santa Catarina, Brazil.

\begin{tabular}{lcc}
\hline Source & Degrees of freedom & Mean square \\
\hline Genotype $(\mathrm{G})$ & 26 & $3,077,991^{* *}$ \\
Year (Y) & 1 & $36,369,792^{* *}$ \\
Environment (E) & 10 & $86,923,754^{* *}$ \\
ExY & 4 & $2,596,208^{* *}$ \\
Block (ExY) & 48 & $386,779^{\text {ns }}$ \\
GxY & 16 & $1,006,609^{* *}$ \\
GxE & 226 & $511,119^{* *}$ \\
GxExY & 61 & $635,551^{* *}$ \\
Residual & 982 & 90,398 \\
\hline Grain yield mean $\left(\mathrm{kg} \mathrm{ha}^{-1}\right)$ & & 2,334 \\
Coefficient of variation $(\%)$ & & 12.88 \\
\hline
\end{tabular}

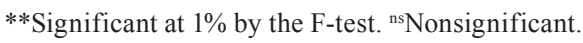


bean cultivar can be recommended for both growing seasons. For maize, the recommendation has a clear separation for the rainy and dry growing season (Uate et al., 2019).

The analysis of stability and productivity is essential when a GxE is detected. Using the GGE biplot methods, stability is measured biologically, that is, the genotype shows a consistent performance among all environments, but it does not respond to environmental improvements (Jamshidmoghaddam \& Pourdad, 2013).

In the joint analysis for the rainy and dry growing seasons, genotype 5 (G5) was the most stable and showed the highest productive average among the evaluated genotypes (Figure 1 A). G6 and G18 ranked second and third, respectively. However, these genotypes were not as stable as G5. In contrast, G8 was stable in the evaluated environments, and was the fourth most productive genotype. Considering the checks, only 'BRS Campeiro' performed better than the average trials. Even with intermediate performance, the checks were adapted and stable in the evaluated environments. This indicated that common bean breeding programs had a tendency to release cultivars with wide adaptation. However, G20 (TB 03-26, mulatinho type) and G21 (TB 03-27, mourinho type) showed low-average production and reduced stability, which occurs with most special grain-type genotypes, making them inadequate for comparisons with black and pinto-type grain genotypes. This occurs because genetic improvement efforts for these grain types are extremely scarce compared to black and pinto-type grains. According to Ribeiro et al. (2014), special grain types are of great importance for their nutritional characteristics.

When the rainy and dry growing seasons were individually evaluated, the highest ranked genotypes changed when compared with the joint analysis and between growing seasons. For the rainy growing season, G8 was the most productive, but showed instability (Figure $1 \mathrm{~B}$ ). G5 was the second most productive genotype, and it was adapted and stable in these environments. Again, G21 and G20 showed the poorest performance, but in inverted positions, in comparison to the joint analysis. In addition, only the check 'BRS Campeiro' performed better than the average of the genotypes of the trials.
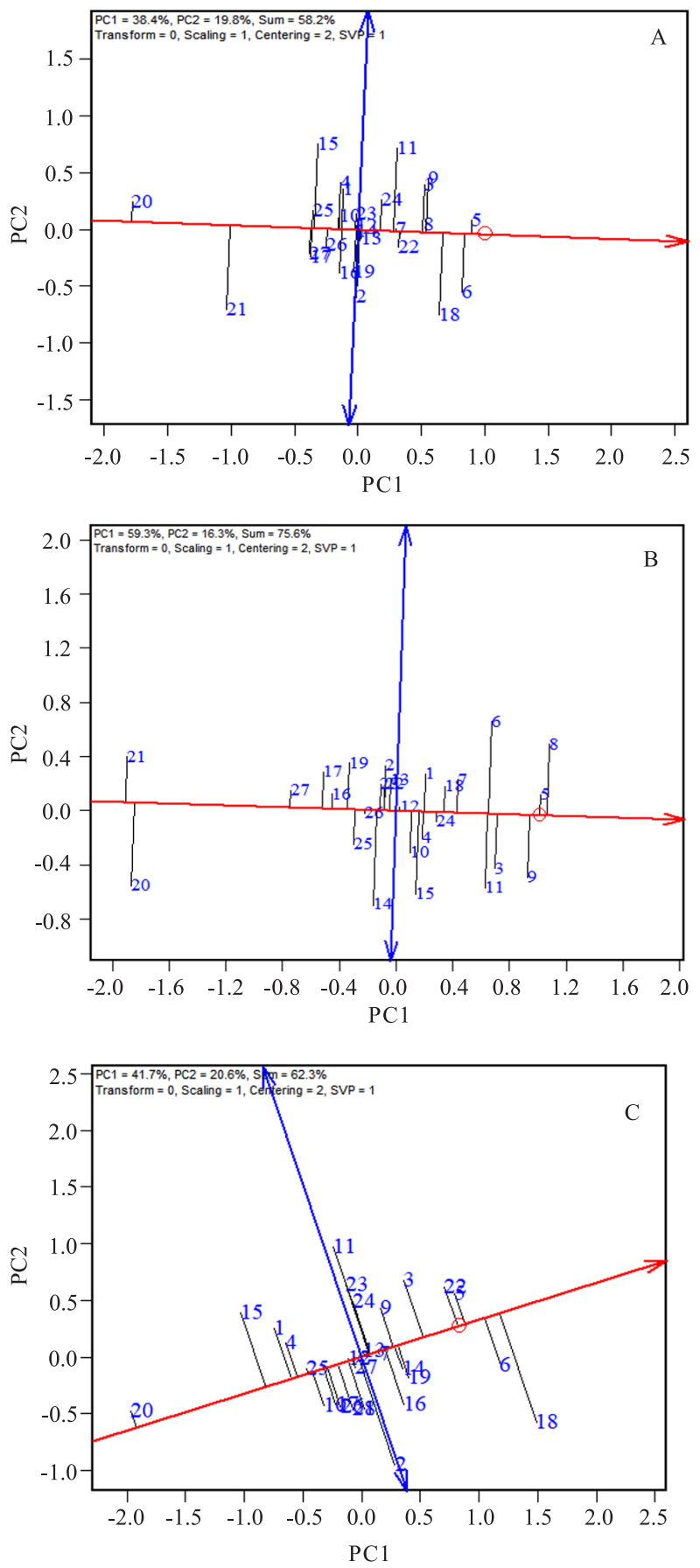

Figure 1. Grain yield and stability of 27 common bean (Phaseolus vulgaris) genotypes evaluated in multienvironment trials, during the 2014/2015 and 2015/2016 crop seasons, in the state of Santa Catarina, Brazil: A, mean and stability of the joint analysis for the rainy and dry growing seasons; B, mean and stability for the rainy growing season; and $\mathrm{C}$, mean and stability for the dry growing season. Genotypes and breeding companies are described in Table 2. PC, principal component. SVP, singular value partitioning. 
The analysis of the dry growing season showed significant changes in relation to the joint analysis. G18 had the greatest productive average, but was highly unstable (Figure $1 \mathrm{C}$ ). G6 was the second most productive and more stable than G18. The genotype G5, the most productive and stable in the joint analysis, ranked third. It showed high productive performance and stability in the evaluated environments.

In addition to being independently assessed, stability and production mean can be assessed using a single index, the "ideal genotype", which represents the ideal performance of a hypothetical genotype that has a maximum yield and high stability (Yan, 2015). A genotype is more desirable, if it is located closer to the circle; this way, G5 was closest to the ideal genotype, indicating that it has wide adaptation and stability (Figure 2). Although G6 showed a certain instability, it was closer to the ideal genotype than G8. This is due to the better productive performance of this genotype.

The analysis of the entry-tester relationship indicates the association between a genotype and a specific environment. Acute angles indicate an elevated association between a genotype and an environment or a group of environments. For the joint analysis, G5 presented the best general performance and was highly associated with environments L41, L42, and L31 (Figure 3 A). Otherwise, G6 and G18 were highly associated with environments L32, L52, and L92.

In the rainy growing season, G5 was again associated with environment L41(Figure 3 B). 'BRS Campeiro' was highly associated with the L21, L61, and L71 environments. These locations are at high altitudes, with climatic conditions that favor the performance of this cultivar. G8 was highly associated with L31. In the dry growing season (Figure $3 \mathrm{C}$ ), G6 was highly associated with most of the environments evaluated in this season (L12, L32, L52, and L92). Otherwise, G5 was associated only with L42.

For plant breeding, it is important to know the ideal (most discriminant and representative) environment to select the most suitable genotypes for the target region. The environments L41 (Chapecó, rainy season), L31 (Canoinhas, rainy season), and L42 (Chapecó, dry season) are highly correlated with the average environment and can be considered the most representative environments (Figure 4). Furthermore, as the most representative environments of the target region, L41 and L42 showed high discrimination ability, with the longest vectors. L31 showed a similar representativeness to the L42 environment, but with a lower discrimination ability. For segregating generations or for breeding stages, when a small number of seed are available, such as in preliminary trials, the Chapecó location (L41 and L42) can be considered ideal for selection for both the rainy and dry growing seasons. Otherwise, L82 and L32 were the least representative locations of the target region. In addition, although L12 presented a median association with the average environment, it showed a low discrimination ability.

The location Chapecó is the closest to ideal environment due the climatic conditions for the cultivation of common bean (Table 1). According to Castro \& Macedo (2011), regions with average temperatures between 17 and $29^{\circ} \mathrm{C}$ are suitable for the production of common bean, but places with average temperatures close to the ideal for the crop $\left(21^{\circ} \mathrm{C}\right)$ are the most suitable locations. It is known that the flower bud stage (R5) is one of the most sensitive stages for common bean. High temperatures $\left(30^{\circ} \mathrm{C}\right.$ during the day and $25^{\circ} \mathrm{C}$ at night) during the $\mathrm{R} 5$ stage, as well as water stress, can greatly increase the rate of miscarriage of flowers and pods (Castro \& Macedo, 2011).

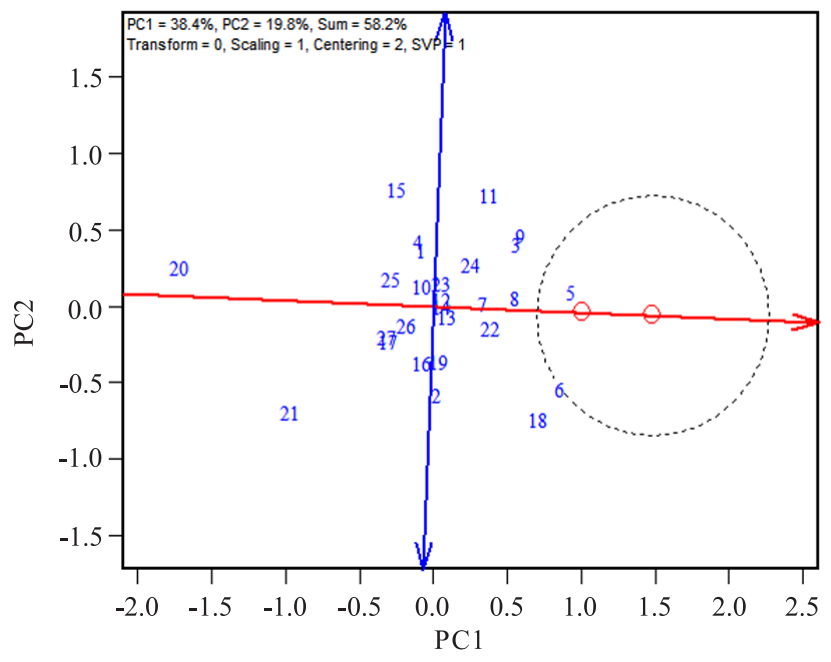

Figure 2. Ideal genotype classification of 27 common bean (Phaseolus vulgaris) genotypes evaluated in multienvironment trials, in the 2014/2015 and 2015/2016 crop seasons, in the state of Santa Catarina, Brazil. Genotypes and breeding companies are described in Table 2. PC, principal component. SVP, singular value partitioning. 

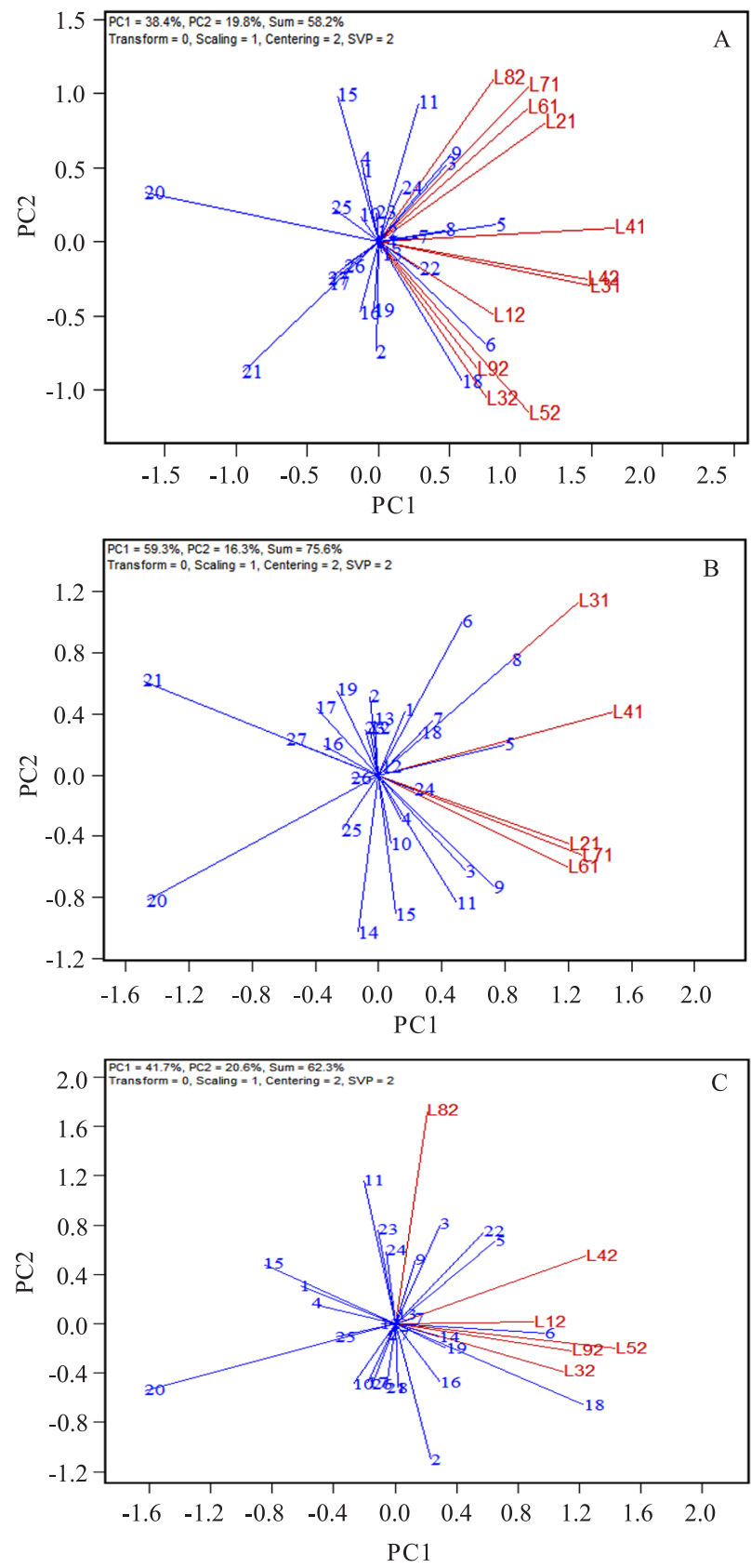

Figure 3. Association between common bean (Phaseolus vulgaris) genotypes and environments, considering together the rainy and dry growing seasons (A), rainy (B), and dry growing season $(\mathrm{C})$, in the state of Santa Catarina, Brazil, in the 2014/2015 and 2015/2016 crop seasons. In red: L12 (Águas de Chapecó, dry); L21 (Campos Novos, rainy); L31 (Canoinhas, rainy); L32 (Canoinhas, dry); L41 (Chapecó, rainy); L42 (Chapecó, dry); L52 (Ituporanga, dry); L61 (Lages, rainy); L71 (Ponte Serrada, rainy); L82 (Urussanga, dry); L92 (Xanxerê, dry). Genotypes and breeding companies are described in Table 2. PC, principal component; SVP, singular value partitioning.
The average altitude of the municipality of Chapecó $(582 \mathrm{~m})$ gives an average annual temperature of $18.1^{\circ} \mathrm{C}$ (Alvares et al., 2013). During the rainy growing season (September to December), an average temperature of approximately $19.1^{\circ} \mathrm{C}$ and precipitation of about $760 \mathrm{~mm}$ were observed. For the dry growing season, from January to May, the average temperature is approximately $19.8^{\circ} \mathrm{C}$, and the precipitation is approximately $830 \mathrm{~mm}$ (Alvares et al., 2013).

It is also worth mentioning that the choice of cultivars by farmers depends on many aspects, including economic, technological, commercial, postharvest and genotypic or phenotypic factors. However, the trait of greatest importance for the success of a genotype is grain yield, and the identification of more adapted and stable materials is essential for the desired success of an improvement program (Kavalco et al., 2018). Other traits, such as disease resistance, growth habit, grain type, cooking time, and grain size, among others, need to be evaluated to confirm a genotype as a new cultivar candidate.

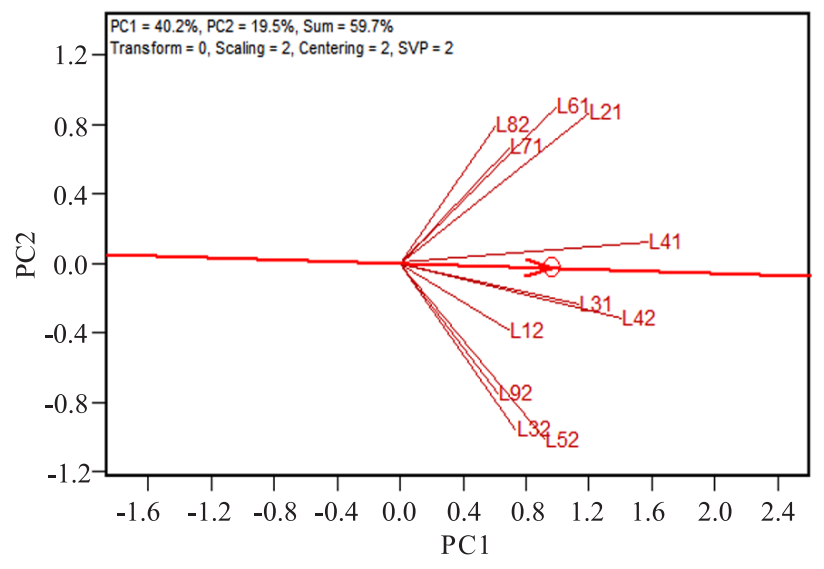

Figure 4. Representativeness and discrimination ability of the environments where 27 common bean (Phaseolus vulgaris) genotypes were evaluated, in the state of Santa Catarina, Brazil, during the 2014/2015 and 2015/20 (16 crop seasons. Environments (location, dry or rainy season): L12 (Águas de Chapecó, dry); L21 (Campos Novos, rainy); L31 (Canoinhas, rainy); L32 (Canoinhas, dry); L41 (Chapecó, rainy); L42 (Chapecó, dry); L52 (Ituporanga, dry); L61 (Lages, rainy); L71 (Ponte Serrada, rainy); L82 (Urussanga, dry); L92 (Xanxerê, dry). PC, principal component; SVP, singular value partitioning. 


\section{Conclusions}

1. Genotype 5 (CHC 01-175-1) is the most productive and stable common bean (Phaseolus vulgaris) genotype, and it can be considered the closest one to the ideal genotype for the target region of Santa Catarina state, Brazil.

2. Chapecó can be considered the ideal location for the selection of common bean genotypes in Santa Catarina state, Brazil, since it shows high representativeness and discrimination ability for this crop cultivation in both the rainy and dry growing seasons.

\section{Acknowledgments}

To Conselho Nacional de Desenvolvimento Científico e Tecnológico (CNPq) and to Coordenação de Aperfeiçoamento Pessoal de Nível Superior (Capes, Finance Code 001), for scholarships granted; to Empresa de Pesquisa Agropecuária e Extensão Rural de Santa Catarina (Epagri) and to Fundação de Apoio à Pesquisa Científica e Tecnológica do Estado de Santa Catarina (Fapesc), for funding.

\section{References}

ALVARES, C.A.; STAPE, J.L.; SENTELHAS, P.C.; GONÇALVES, J.L. de M.; SPAROVEK, G. Köppen's climate classification map for Brazil. Meteorologische Zeitschrift, v.22, p.711-728, 2013. DOI: https//doi.org/10.1127/0941-2948/2013/0507.

BORNHOFEN, E.; BENIN, G.; STORCK, L.; WOYANN, L.G.; DUARTE, T.; STOCO, M.G.; MARCHIORO, S.V. Statistical methods to study adaptability and stability of wheat genotypes. Bragantia, v.76, p.1-10, 2017. DOI: https//doi.org/10.1590/16784499.557.

CARVALHO, L.C.B.; DAMASCENO-SILVA, K.J.; ROCHA, M. de M.; OLIVEIRA, G.C.X. Evolution of methodology for the study of adaptability and stability in cultivated species. African Journal of Agricultural Research, v.11, p.990-1000, 2016. DOI: https//doi.org/10.5897/AJAR2015.10596.

CASTRO, P.R. de C. e; MACEDO, W.R. Fisiologia do feijoeiro e perspectivas para o uso de agroquímicos hormonais. In: FANCELLI, A.L. (Ed.). Feijão: tecnologia da produção. Piracicaba: ESALQ, 2011. p.81-98.

COMISSÃO TÉCNICA SUL-BRASILEIRA DE FEIJÃO. Informações técnicas para o cultivo de feijão na Região Sul brasileira. 2.ed. Florianópolis: Epagri, 2012. 157p.

CONAB. Companhia Nacional de Abastecimento. Série histórica das safras. Available at: <https:/www.conab.gov.br/info-agro/ safras/serie-historica-das-safras>. Accessed on: Feb. 12021.
FAO. Food and Agriculture Organization of the United Nations. Faostat: crops. Available at: <http://www.fao.org/faostat/ en/\#data/QC/visualize>. Accessed on: Feb. 12021.

FERREIRA, C.M.; FIGUEIREDO, R.S.; ALBERNAZ LUZ, T.C. de L. Arroz e feijão: intervenção multi-institucional em prol do Brasil. Revista de Política Agrícola, v.27, p.96-112, 2018.

JAMSHIDMOGHADDAM, M.; POURDAD, S.S. Genotype $\times$ environment interactions for seed yield in rainfed winter safflower (Carthamus tinctorius L.) multi-environment trials in Iran. Euphytica, v.190, p.357-369, 2013. DOI: https//doi.org/10.1007/ s10681-012-0776-z.

KAVALCO, S.A.F.; NICKNICH, W.; VIEIRA NETO, J.; CRISPIM, J.E.; VOGT, G.A.; COIMBRA, J.L.M. Adaptabilidade e estabilidade de cultivares e linhagens de feijão no estado de Santa Catarina. Agropecuária Catarinense, v.31, p.62-66, 2018. DOI: https://doi.org/10.22491/RAC.2018.v31n3.8.

MATEI, G.; BENIN, G.; WOYANN, L.G.; DALLÓ, S.C.; MILIOLI, A.S.; ZDZIARSKI, A.D. Agronomic performance of modern soybean cultivars in multi-environment trials. Pesquisa Agropecuária Brasileira, v.52, p.500-511, 2017. DOI: https//doi.org/10.1590/s0100-204x2017000700004.

POTTER, R.O.; CARVALHO, A.P. de; FLORES, C.A.; BOGNOLA, I. Solos do estado de Santa Catarina. Rio de Janeiro: Embrapa Solos, 2004. 721p. (Embrapa Solos. Boletim de pesquisa e desenvolvimento, 46).

QIN, J.; XU, R.; LI, H.; YANG, C.; LIU, D.; LIU, Z.; ZHANG, L.; LU, W.; FRETT, T.; CHEN, P.; ZHANG, M.; QIU, L. Evaluation of productivity and stability of elite summer soybean cultivars in multi-environment trials. Euphytica, v.206, p.759-773, 2015. DOI: https//doi.org/10.1007/s10681-015-1513-1.

RIBEIRO, N.D.; RODRIGUES, J. de A.; PRIGOL, M.; NOGUEIRA, C.W.; STORCK, L.; GRUHN, E.M. Evaluation of special grains bean lines for grain yield, cooking time and mineral concentrations. Crop Breeding and Applied Biotechnology, v.14, p.15-22, 2014. DOI: https//doi.org/10.1590/ S1984-70332014000100003.

SANTOS, P.R. de; OLIVEIRA, T.R.A. de; SKEEN, P.; NASCIMENTO, M.R.; COSTA, K.D. da S.; ARAÚJO, E.R.; PEREIRA, H.S.; COSTA, A.F. da. GGE biplot and REML/BLUP based-analysis of yield stability and adaptability for common beans in multi-environment trials. Revista Brasileira de Ciências Agrárias, v.14, e5657, 2019. DOI: https://doi.org/10.5039/agraria. v14i2a5657.

UATE, J.V.; NUVUNGA, J.J.; SILVA, C.P. da; GUIMARÃES, L.J.M.; VON PINHO, R.G.; BALESTRE, M. Genetic progress, adaptability and stability of maize cultivars for value of cultivation and use trials. Acta Scientiarum. Agronomy, v.41, e42624, 2019. DOI: https://doi.org/10.4025/actasciagron.v41i1.42624.

VAN EEUWIJK, F.A.; BUSTOS-KORTS, D.V.; MALOSETTI, M. What should students in plant breeding know about the statistical aspects of genotype $\times$ environment interactions? Crop Science, v.56, p.2119-2140, 2016. DOI: https://doi.org/10.2135/ cropsci2015.06.0375.

WOYANN, L.G.; ZDZIARSKI, A.D.; BARETTA, D.; MEIRA, D.; DALLACORTE, L.V.; BENIN, G. Selection of high-yielding,

Pesq. agropec. bras., Brasília, v.56, e02302, 2021

DOI: 10.1590/S1678-3921.pab2021.v56.02302 
adapted and stable wheat lines in preliminary trials. Crop Breeding and Applied Biotechnology, v.19, p.412-419, 2019. DOI: https://doi.org/10.1590/1984-70332019v19n4a58.

YAN, W. Crop variety trials: data management and analysis. Chichester: J. Wiley \& Sons, 2014. 351p. DOI: https://doi.org/10.1002/9781118688571.

YAN, W. GGEbiplot - A Windows application for graphical analysis of multienvironment trial data and other types of twoway data. Agronomy Journal, v.93, p.1111-1118, 2001. DOI: https://doi.org/10.2134/agronj2001.9351111x.

YAN, W. Mega-environment analysis and test location evaluation based on unbalanced multiyear data. Crop Science, v.55, p.113122, 2015. DOI: https://doi.org/10.2135/cropsci2014.03.0203.
ZANELLA, R.; MEIRA, D.; ZDZIARSKI, A.D.; BRUSAMARELLO, A.P.; OLIVEIRA, P. H. de; BENIN, G. Performance of common bean genotypes as a function of growing seasons and technological input levels. Pesquisa Agropecuária Tropical, v.49, e54989, 2019. DOI: https://doi.org/10.1590/198340632019v4954989.

ZIMMERMANN, A.; WEBBER, H.; ZHAO, G.; EWERT, F.; KROS, J.; WOLF, J.; BRITZ, W.; DE VRIES, W. Climate change impacts on crop yields, land use and environment in response to crop sowing dates and thermal time requirements. Agricultural Systems, v.157, p.81-92, 2017. DOI: https://doi.org/10.1016/j. agsy.2017.07.007. 